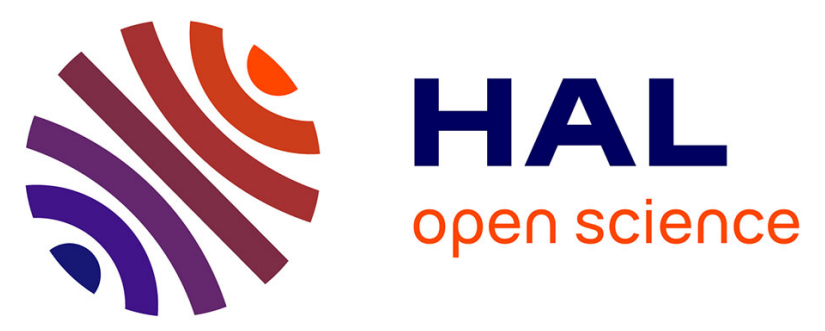

\title{
How the Acidic Milieu Interferes in the Capability of Ruthenium Nitrosyl Complexes to Release Nitric Oxide?
}

Renato Pereira Orenha, Nelson Henrique Morgon, Julia Contreras-García, Graziele Cappato Guerra Silva, Glaucio Régis Nagurniak, Maurício Jeomar Piotrowski, Giovanni Finoto Caramori, Alvaro Muñoz-Castro, Renato Luis Tame Parreira

\section{To cite this version:}

Renato Pereira Orenha, Nelson Henrique Morgon, Julia Contreras-García, Graziele Cappato Guerra Silva, Glaucio Régis Nagurniak, et al.. How the Acidic Milieu Interferes in the Capability of Ruthenium Nitrosyl Complexes to Release Nitric Oxide?. New Journal of Chemistry, 2020, 44 (3), pp.773-779. 10.1039/C9NJ04643G . hal-03371961

\section{HAL Id: hal-03371961 https://hal.science/hal-03371961}

Submitted on 9 Oct 2021

HAL is a multi-disciplinary open access archive for the deposit and dissemination of scientific research documents, whether they are published or not. The documents may come from teaching and research institutions in France or abroad, or from public or private research centers.
L'archive ouverte pluridisciplinaire HAL, est destinée au dépôt et à la diffusion de documents scientifiques de niveau recherche, publiés ou non, émanant des établissements d'enseignement et de recherche français ou étrangers, des laboratoires publics ou privés. 


\section{ARTICLE}

\section{How the Acidic Milieu Interferes in the Capability of Ruthenium Nitrosyl Complexes to Release Nitric Oxide?}

Received 00th January 20xx, Accepted 00th January 20xx DOI: $10.1039 / x 0 x \times 00000 x$

\author{
Renato Pereira Orenha, ${ }^{* a}$ Nelson Henrique Morgon, ${ }^{\mathrm{b}}$ Julia Contreras-García, ${ }^{\mathrm{c}}$ Graziele Cappato \\ Guerra Silva, ${ }^{a}$ Glaucio Régis Nagurniak, ${ }^{d}$ Maurício Jeomar Piotrowski, ${ }^{d}$ Giovanni Finotto Caramori, \\ Alvaro Muñoz-Castro ${ }^{f}$ and Renato Luis Tame Parreira*a
}

\section{Introduction}

The nitric oxide (NO) compound is one of the ten smallest stable molecules in nature. ${ }^{1}$ The most important features of NO comprise: small size; uncharged; and holds an unpaired electron. The first two characteristics ensure to NO a high and constant diffusion, allowing it to travel long distances in an extremely short time. ${ }^{2}$ On the other hand, the presence of an unpaired electron is essential to control its chemical reactivity. ${ }^{3}$

Many years ago, NO molecule was merely associated with

a. Núcleo de Pesquisas em Ciências Exatas e Tecnológicas, Universidade de Franca 14404-600, Franca, SP, Brazil.E-mail: rpo9@hotmail.com /

renato.parreira@unifran.edu.br

b. Instituto de Química, Universidade Estadual de Campinas, CP 6154, 13083-970, Campinas, SP, Brazil.

Sorbonne Université, CNRS, Laboratoire de Chimie Théorique, LCT, F. 75005 Paris, France.

d. Department of Physics, Federal University of Pelotas, PO Box 354, 96010-900, Pelotas, RS, Brazil.

e. Departamento de Química, Universidade Federal de Santa Catarina, Campus Universitário Trindade, CP 476, Florianópolis, SC, 88040-900, Brazil.

f. Laboratorio de Química Inorgánica y Materiales Moleculares, Facultad de Ingenieria, Universidad Autonoma de Chile, Llano Subercaceaux 2801, San Miguel, Santiago, Chile.

+ Electronic Supplementary Information (ESI) available: Cartesian coordinates of the optimized geometries, electronic energy $(\Delta E)$ to selected complexes studied in this paper. QTAIM results to $\left[\mathrm{Ru}(\mathrm{HNO})\left(\mathrm{H}_{2} \mathrm{O}\right)\left(\mathrm{NH}_{3}\right)_{5}\right]^{3+}+8 \mathrm{H}_{2} \mathrm{O}$. See DOI: $10.1039 / x 0 x x 00000 x$ different phenomena of atmospheric pollution, such as, the greenhouse effect, acid rain, and the destruction of the ozone layer. ${ }^{4}$ However, along of the years, researchers have discovered that the NO molecule is also involved in numerous physiological and physiopathological routes as, for instance, acting as a biological messenger, showing crucial roles in neurotransmission, and also being fundamental in the learning and memorization processes. ${ }^{5-8}$

From the fact that the nitric oxide can be dangerous or beneficial, depending on its concentration and availability, ${ }^{9}$ compounds with the ability to donor or scavenger NO from biological environments are of great interest. It is important to highlight that Ru-NO coordination compounds containing ammine ligands have been extensively used as experimental and theoretical models to investigate the release of NO group. ${ }^{10-13}$

Different ways can be used to control the lability of the RuNO chemical bond in coordination compounds. ${ }^{14}$ The release of the nitric oxide is usually proposed to occur in different steps, involving the chemical reduction of $\mathrm{NO}^{+}$to $\mathrm{NO}^{0}$, followed by a substitution reaction of $\mathrm{NO}^{0}$ in the coordination sphere by a water molecule (Scheme $1(\mathbf{a}$ and $\mathbf{b})$ ). 


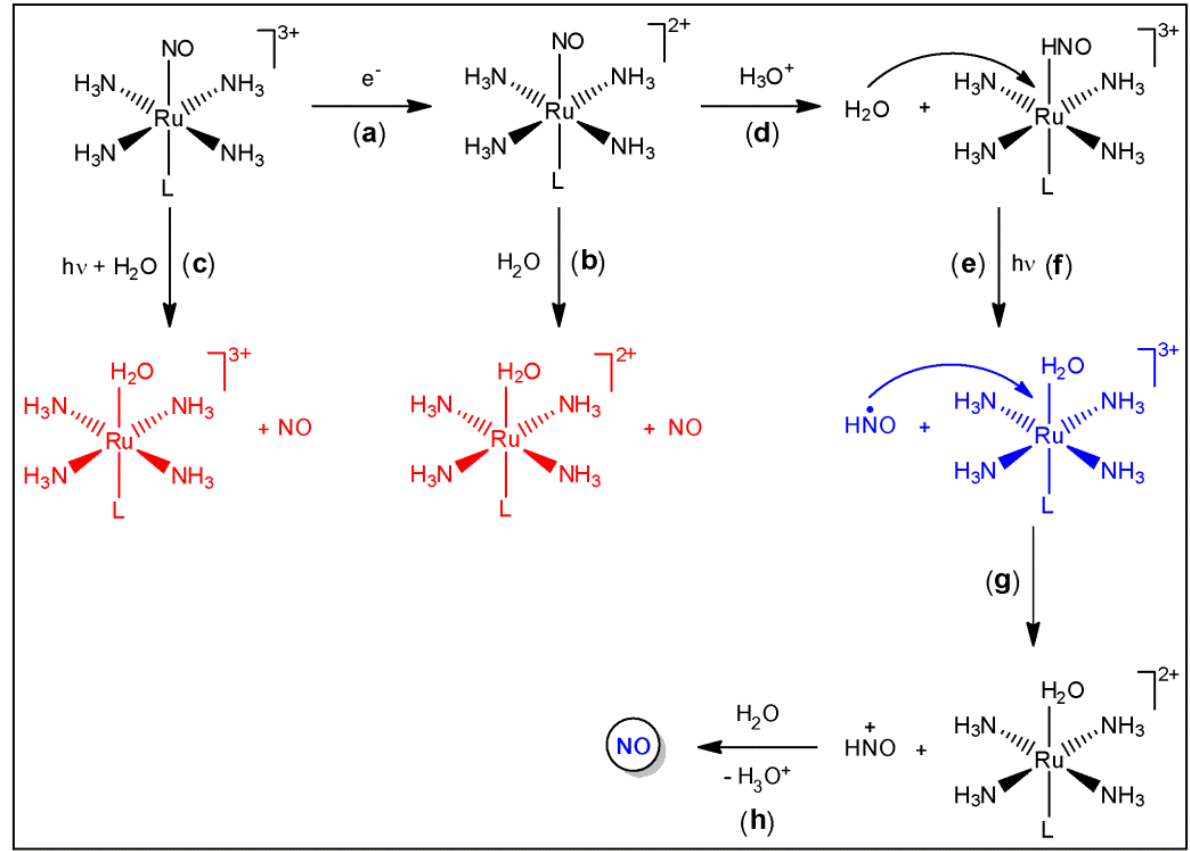

Scheme 1 Representation of the main NO release mechanisms from typical ruthenium(II) compounds through ligand substitution reaction $\mathrm{H}_{2} \mathrm{O} \rightarrow$ NO after the: reduction reaction ( $\mathbf{a}$ and $\mathbf{b})$; and light irradiation $(\mathbf{c})$. Proposed mechanism to $\mathrm{NO}$ release through: protonation of the $\left[\mathrm{Ru}(\mathrm{NO})\left(\mathrm{NH}_{3}\right)_{5}\right]^{2+}$ reduced complex $(\mathbf{d}, \mathbf{e}, \mathbf{g}$ and h); and light irradiation $(\mathbf{f}-\mathbf{h})$ of the $\left[\mathrm{Ru}(\mathrm{HNO})\left(\mathrm{NH}_{3}\right)_{5}\right]^{3+}$ molecule.

However, when $\mathrm{L}=\mathrm{Cl}^{-}$, the substitution of this ligand by $\mathrm{H}_{2} \mathrm{O}$ occurs before the substitution reaction of the NO ligand by water. ${ }^{15}$ Another way suggested to promote the NO substitution by $\mathrm{H}_{2} \mathrm{O}$ involves the light irradiation in the $\lambda=300$ - $600 \mathrm{~nm}$ spectrum domain (Scheme 1(c)). ${ }^{16,17}$ However, both mechanisms were recently contested in the literature where theoretical and experimental investigations showed that the nitric oxide release not occurs from only a reduction reaction or a light assisted chemical reaction. ${ }^{18,19}$

Due to the continuous interest involved in elucidating the study of Ru-NO complexes, ${ }^{20-22}$ in this paper we propose NO release mechanisms from one typical Ru-NO coordination compound: $\left[\mathrm{Ru}(\mathrm{II})\left(\mathrm{NO}^{+}\right)\left(\mathrm{NH}_{3}\right)_{5}\right]^{3+}$. Here, the fact that the typical chemical reactions for $\mathrm{NO}$ release occurs in acid environments is taken into account. ${ }^{15}$ The importance of the reactional details can be observed in the recent investigation performed in the catalytic reaction of the $\mathrm{N}_{2} \mathrm{O}$ hydrogenation (to produce $\mathrm{N}_{2}$ and $\mathrm{H}_{2} \mathrm{O}$ molecules) from DFT calculations, which show that one $\mathrm{H}_{2} \mathrm{O}$ molecule develops an essential role to decrease the energy barrier for the $\mathrm{N}_{2}$ liberation. ${ }^{23,24}$ Thus, the typical reaction profile (Scheme 1(a and $\mathbf{b})$ ) will be compared with the proposed in this paper (Scheme $1(\mathbf{a}, \mathbf{d}, \mathbf{e}, \mathbf{g}$ and $\mathbf{h})$ ) with the objective to explain how the $\mathrm{H}_{3} \mathrm{O}^{+}$cation influence in both thermodynamic and kinetic descriptions. Furthermore, the light irradiation relevance is explored in the NO release mechanism proposed in this paper (Scheme $1(\mathbf{a}, \mathbf{d}$ and $\mathbf{f}-\mathbf{h})$ ). The importance of the number of explicit water molecules around the $\left[\mathrm{Ru}(\mathrm{HNO})\left(\mathrm{NH}_{3}\right)_{5}\right]^{3+}+\mathrm{n} \mathrm{H}_{2} \mathrm{O} \rightarrow\left[\mathrm{Ru}\left(\mathrm{H}_{2} \mathrm{O}\right)\left(\mathrm{NH}_{3}\right)_{5}\right]^{3+}+$ $\mathrm{HNO}+\mathrm{n}-1 \mathrm{H}_{2} \mathrm{O}$ chemical reaction (Scheme $1(\mathbf{e}$ and $\mathbf{f})$ ), to $\mathrm{n}=1$ and 9 , is also explored. The distribution of partial electronic charges is computed via the atomic polar tensor (APT) formalism. The density electron topological analysis is performed in the light of Quantum Theory of Atoms in Molecules (QTAIM) and Non-Covalent Interactions (NCI) methodologies with the purpose of further rationalizing the mechanisms proposed in this study.

\section{Computational Methods}

\subsection{Computational Details}

The geometry of all studied compounds was optimized without restraints, and the vibrational frequencies were calculated from the PBE025-27 method along with the Def2TZV basis set. ${ }^{28,29}$ Vibrational analyses for all optimized geometries 
validate that they are all energy minima (without imaginary frequencies) and transition states (one imaginary frequency related the NO release displacement) at the level of theory applied here. NO release was modeled using potential energy surface scanning, and the transition states were obtained using the QST2 method. ${ }^{30}$ The Intrinsic Reaction Coordinate (IRC) method was also used to confirm the transition state structures. An energy threshold of $10^{-8}$ a.u was used for selfconsistency, whereas for geometry optimizations, the Root-Mean-Square (RMS) force criterion was set to $3^{*} 10^{-4}$ a.u. The wavefunction of the compounds in investigation were determined from PBEO/Def2TZVP28 computational model. The electronic energy $(\Delta E)$ and entropy $(\Delta S)$ were calculated from PBE0-D3(BJ) ${ }^{31} /$ Def2TZVP computational model and used as base to describe the reaction profiles. The electronic spectrum was obtained from TD-PBEO/Def2TZVP computational approaches. The water solvation was considered from the Polarizable Continuum Model (PCM) using the integral equation formalism variant (IEFPCM). ${ }^{32}$ The distribution of partial electronic charges was calculated from the atomic polar tensor (APT) method. ${ }^{33}$ These calculations were performed from Gaussian 16 Revision A.03 software. ${ }^{34}$ The topological analysis of the electron density was executed from the Quantum Theory of Atoms in Molecules (QTAIM) method through the AIMAll (Version 17.01.25) software. ${ }^{35} \mathrm{NCI}$ analysis ${ }^{36}$ was carried out with NCIPLOT. ${ }^{37}$

\subsection{Quantum Theory of Atoms in Molecules}

The interpretation of $\nabla^{2} \rho_{b}$ is obtained from the Virial theorem of the total electron density. In this theorem, the kinetic energy $G_{b}$ (positive values) and potential $V_{b}$ (negative values) are correlated (Equation 1).

$1 / 4 \nabla^{2} \rho_{b}=2 G_{b}+V_{b}$

The $-G_{b} / V_{b}$ ratio is also used as an efficient topological descriptor. One value of $-G_{b} / V_{b}>1.0$ represents non-covalent interactions. Values of $-G_{b} / V_{b}$ between 0.5 and 1.0 are related with partially covalent interactions. Lastly, $-G_{b} / V_{b}$ values lower than 0.5 indicate covalent bonds. ${ }^{38,39}$

\section{Results and Discussion}

The geometric parameters obtained from geometry optimization of the complex $\left[\mathrm{Ru}(\mathrm{NO})\left(\mathrm{NH}_{3}\right)_{5}\right]^{3+}$, explicitly solvated with one $\mathrm{H}_{2} \mathrm{O}$ molecule, $\left[\mathrm{Ru}(\mathrm{NO})\left(\mathrm{NH}_{3}\right)_{5}\right]^{3+}+\mathrm{H}_{2} \mathrm{O}$, through PBEO/Def2TZV computational model with PCM $\left(\mathrm{H}_{2} \mathrm{O}\right)$ solvation, are summarized in the Supplementary Material (Tables S1 and S2). The calculated results show close values to the experimental values obtained from X-ray diffraction. ${ }^{40}$ It supports the accuracy of the computational model chosen to investigate these coordination compounds.

Initially, the reduction chemical reaction: $\left[\mathrm{Ru}(\mathrm{NO})\left(\mathrm{NH}_{3}\right)_{5}\right]^{3+}$ $+\mathrm{e}^{-}+\mathrm{H}_{2} \mathrm{O} \rightarrow\left[\mathrm{Ru}(\mathrm{NO})\left(\mathrm{NH}_{3}\right)_{5}\right]^{2+}+\mathrm{H}_{2} \mathrm{O}$ shows a decrease of the electronic energy $(\Delta E)$ equal to $-79.97 \mathrm{kcal} \mathrm{mol}^{-1}$, attesting to thermodynamically favorable nature. The analysis of the reaction profile of the $\left[\mathrm{Ru}(\mathrm{NO})\left(\mathrm{NH}_{3}\right)_{5}\right]^{2+}+\mathrm{H}_{2} \mathrm{O} \rightarrow$ $\left[\mathrm{Ru}\left(\mathrm{H}_{2} \mathrm{O}\right)\left(\mathrm{NH}_{3}\right)_{5}\right]^{2+}+\mathrm{NO}$ chemical reaction shows that from the reactants, $\left[\mathrm{Ru}(\mathrm{NO})\left(\mathrm{NH}_{3}\right)_{5}\right]^{2+}+\mathrm{H}_{2} \mathrm{O}$, to the products, $\left[\mathrm{Ru}\left(\mathrm{H}_{2} \mathrm{O}\right)\left(\mathrm{NH}_{3}\right)_{5}\right]^{2+}+\mathrm{NO}$, there is one transition state, $\left[\mathrm{Ru}\left(\mathrm{H}_{2} \mathrm{O}\right)(\mathrm{NO})\left(\mathrm{NH}_{3}\right)_{5}\right]^{2+}$ (Scheme 2). Thus, for this reaction to occur it is necessary that the ruthenium atom interacts with the $\mathrm{H}_{2} \mathrm{O}$ molecule leading to a heptacoordinate compound. A hydrogen atom from $\mathrm{H}_{2} \mathrm{O}$ is positioned directed to $\mathrm{NO}$ nitrogen atom enabling an $\mathrm{HOH} \cdots \mathrm{NO}$ hydrogen bond interaction, driven by the fact that the nitrogen atom of $\mathrm{NO}$ has an unpaired electron. ${ }^{41}$ In the last step, the $\mathrm{Ru}-\mathrm{H}_{2} \mathrm{O}$ chemical bond adopts a linear configuration $\left(\mathrm{NH}_{3}\right)_{\text {trans }}-\mathrm{Ru}-\mathrm{H}_{2} \mathrm{O}$, while keeping the $\mathrm{HOH} \cdots \mathrm{NO}$ hydrogen bond at this extend. However, the reaction profiles indicate, in the first place, that the $\left[\mathrm{Ru}(\mathrm{NO})\left(\mathrm{NH}_{3}\right)_{5}\right]^{2+}+$ $\mathrm{H}_{2} \mathrm{O} \rightarrow\left[\mathrm{Ru}\left(\mathrm{H}_{2} \mathrm{O}\right)\left(\mathrm{NH}_{3}\right)_{5}\right]^{2+}+\mathrm{NO}$ chemical reaction is not thermodynamically favorable because there is an increase in electronic energy from the reactants to the products $(31.37$ $\mathrm{kcal} \mathrm{mol}^{-1}$ ). Furthermore, the significantly high value $\mathrm{e}^{42}$ of the energy barrier present between $\left[\mathrm{Ru}(\mathrm{NO})\left(\mathrm{NH}_{3}\right)_{5}\right]^{2+}+\mathrm{H}_{2} \mathrm{O}$ and $\left[\mathrm{Ru}\left(\mathrm{H}_{2} \mathrm{O}\right)(\mathrm{NO})\left(\mathrm{NH}_{3}\right)_{5}\right]^{2+}\left(45.95 \mathrm{kcal} \mathrm{mol}^{-1}\right)$ also points out in the proposed chemical reaction being excessively low in temperature.

Thus, as the traditional mechanism proposed for NO release showed an energetic profile that does not agree with the experimental evidence, herein we propose an alternative mechanism to elucidate how the nitric oxide can be available from ruthenium coordination compounds. For this purpose, the fact that the $\left[\mathrm{Ru}(\mathrm{NO})\left(\mathrm{NH}_{3}\right)_{5}\right]^{2+}+\mathrm{H}_{2} \mathrm{O} \rightarrow\left[\mathrm{Ru}\left(\mathrm{H}_{2} \mathrm{O}\right)\left(\mathrm{NH}_{3}\right)_{5}\right]^{2+}+$ $\mathrm{NO}$ chemical reaction occurs in acid environment will be considered in the first place. The $\left[\mathrm{Ru}(\mathrm{NO})\left(\mathrm{NH}_{3}\right)_{5}\right]^{2+}+\mathrm{H}_{3} \mathrm{O}^{+} \rightarrow$ $\left[\mathrm{Ru}(\mathrm{HNO})\left(\mathrm{NH}_{3}\right)_{5}\right]^{3+}+\mathrm{H}_{2} \mathrm{O}$ reaction leads to an electronic energy difference between the products and reactants of $10.10 \mathrm{kcal}$ $\mathrm{mol}^{-1}$, being thermodynamically accessible this first step.

At the second step, $\left[\mathrm{Ru}(\mathrm{HNO})\left(\mathrm{NH}_{3}\right)_{5}\right]^{3+}+\mathrm{H}_{2} \mathrm{O} \rightarrow$ $\left[\mathrm{Ru}\left(\mathrm{H}_{2} \mathrm{O}\right)\left(\mathrm{NH}_{3}\right)_{5}\right]^{3+}+\mathrm{HNO}$, the process is thermodynamically unfavorable (21.59 kcal mol-1), however, in a lower energy magnitude than that observed from $\left[\mathrm{Ru}(\mathrm{NO})\left(\mathrm{NH}_{3}\right)_{5}\right]^{2+}+\mathrm{H}_{2} \mathrm{O}$ to $\left[\mathrm{Ru}\left(\mathrm{H}_{2} \mathrm{O}\right)\left(\mathrm{NH}_{3}\right)_{5}\right]^{2+}+\mathrm{NO}\left(31.37 \mathrm{kcal} \mathrm{mol}^{-1}\right)$. In addition, the reactants composed by $\left[\mathrm{Ru}(\mathrm{HNO})\left(\mathrm{NH}_{3}\right)_{5}\right]^{3+}+\mathrm{H}_{2} \mathrm{O}$ structure shows that the oxygen atom from the water forms two hydrogen bonds (Scheme 2). The first one occurs with one $\mathrm{NH}_{3}$ ligand: $\mathrm{H}_{2} \mathrm{O} \cdots \mathrm{NH}_{3}$, and the second one with the $\mathrm{HNO}$ ligand: $\mathrm{H}_{2} \mathrm{O} \cdots \cdot \mathrm{HNO}$. This second hydrogen bond keeps the $\mathrm{H}_{2} \mathrm{O}$ molecule closer to $\mathrm{HNO}$ group than it was to the NO group in $\left[\mathrm{Ru}(\mathrm{NO})\left(\mathrm{NH}_{3}\right)_{5}\right]^{2+}+\mathrm{H}_{2} \mathrm{O}$. Consequently, from $\left[\mathrm{Ru}(\mathrm{HNO})\left(\mathrm{NH}_{3}\right)_{5}\right]^{3+}$ $+\mathrm{H}_{2} \mathrm{O}$ to the transition state $\left[\mathrm{Ru}(\mathrm{HNO})\left(\mathrm{H}_{2} \mathrm{O}\right)\left(\mathrm{NH}_{3}\right)_{5}\right]^{3+}$ the energy barrier found is lower than the one showed by the traditional NO release mechanism (it does down from 45.95 to $\left.31.80 \mathrm{kcal} \mathrm{mol}^{-1}\right)$. Lastly, from $\left[\mathrm{Ru}(\mathrm{HNO})\left(\mathrm{H}_{2} \mathrm{O}\right)\left(\mathrm{NH}_{3}\right)_{5}\right]^{3+}$ to $\left[\mathrm{Ru}\left(\mathrm{H}_{2} \mathrm{O}\right)\left(\mathrm{NH}_{3}\right)_{5}\right]^{3+}+\mathrm{HNO}$ the $\mathrm{H}_{2} \mathrm{O}$ adopts a linear geometry with $\mathrm{Ru}$ and the $\mathrm{NH}_{3}$ trans ligand, while the distance between the HNO group and the metal complex increases. It should be noted that the $\left[\mathrm{Ru}(\mathrm{HNO})\left(\mathrm{NH}_{3}\right)_{5}\right]^{3+}+\mathrm{H}_{2} \mathrm{O}$, $\left[\mathrm{Ru}(\mathrm{HNO})\left(\mathrm{H}_{2} \mathrm{O}\right)\left(\mathrm{NH}_{3}\right)_{5}\right]^{3+}$ and $\left[\mathrm{Ru}\left(\mathrm{H}_{2} \mathrm{O}\right)\left(\mathrm{NH}_{3}\right)_{5}\right]^{3+}+\mathrm{HNO}$ energy values are lower than $\left[\mathrm{Ru}(\mathrm{NO})\left(\mathrm{NH}_{3}\right)_{5}\right]^{2+}+\mathrm{H}_{2} \mathrm{O}$, $\left[\mathrm{Ru}\left(\mathrm{H}_{2} \mathrm{O}\right)(\mathrm{NO})\left(\mathrm{NH}_{3}\right)_{5}\right]^{2+}$ and $\left[\mathrm{Ru}\left(\mathrm{H}_{2} \mathrm{O}\right)\left(\mathrm{NH}_{3}\right)_{5}\right]^{2+}+\mathrm{NO}$, respectively (Table $\mathrm{S} 3$ ). 


\section{ARTICLE}

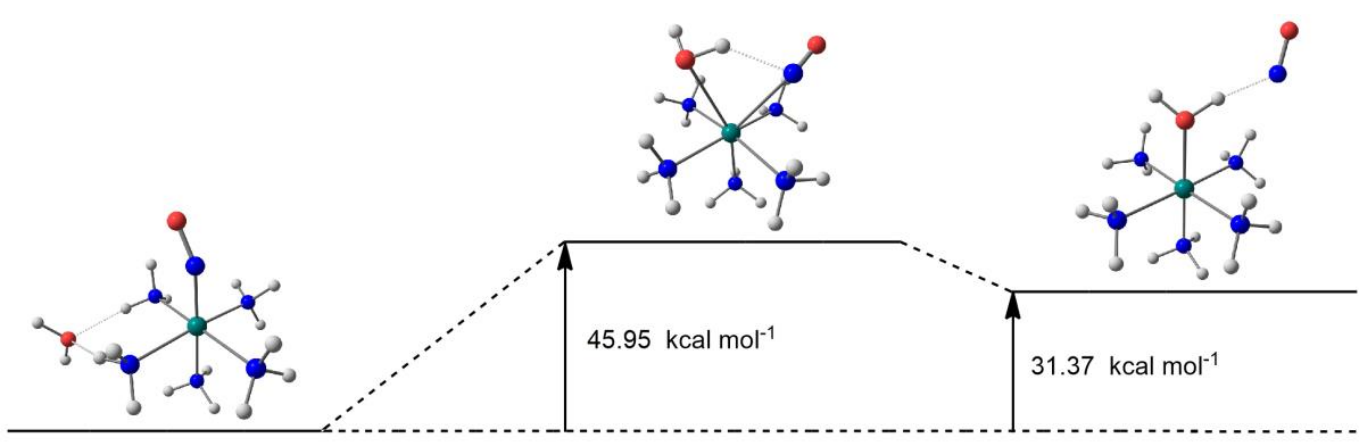

(a)

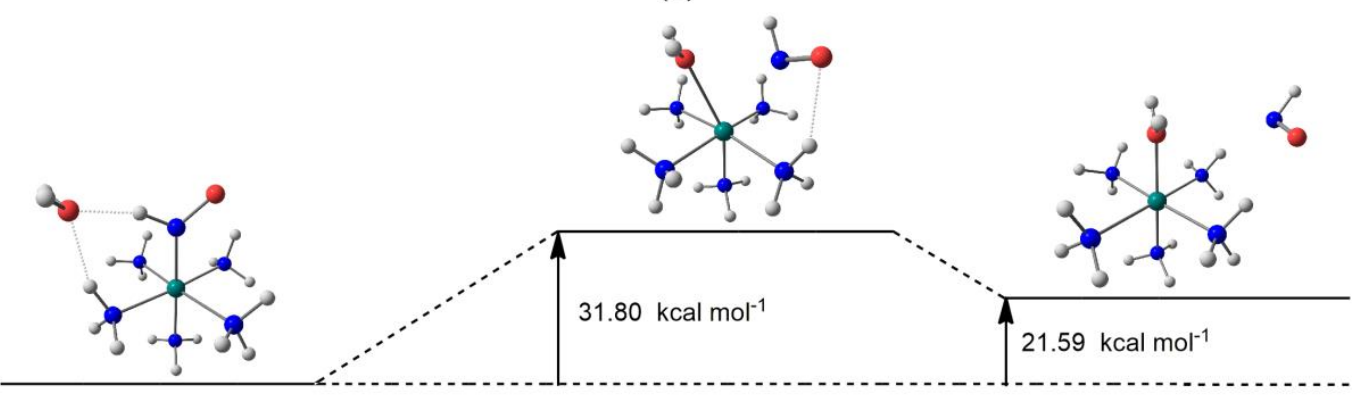

(b)

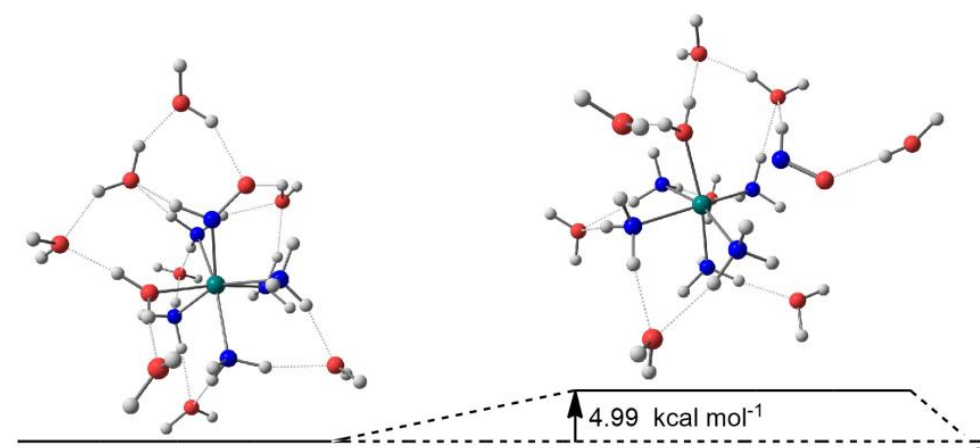

(c)

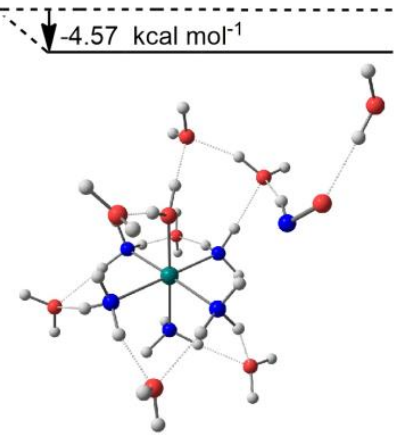

Scheme 2 Energy surface for the: (a) $\left[\mathrm{Ru}(\mathrm{NO})\left(\mathrm{NH}_{3}\right)_{5}\right]^{2+}+\mathrm{H}_{2} \mathrm{O} \rightarrow\left[\mathrm{Ru}\left(\mathrm{H}_{2} \mathrm{O}\right)\left(\mathrm{NH}_{3}\right)_{5}\right]^{2+}+\mathrm{NO}$; (b) $\left[\mathrm{Ru}(\mathrm{HNO})\left(\mathrm{NH}_{3}\right)_{5}\right]^{3+}+\mathrm{H}_{2} \mathrm{O} \rightarrow\left[\mathrm{Ru}\left(\mathrm{H}_{2} \mathrm{O}\right)\left(\mathrm{NH}_{3}\right)_{5}\right]^{3+}+\mathrm{HNO}$; and $(\mathbf{c})$ $\left[\mathrm{Ru}(\mathrm{HNO})\left(\mathrm{NH}_{3}\right)_{5}\right]^{3+}+9 \mathrm{H}_{2} \mathrm{O} \rightarrow\left[\mathrm{Ru}\left(\mathrm{H}_{2} \mathrm{O}\right)\left(\mathrm{NH}_{3}\right)_{5}\right]^{3+}+\mathrm{HNO}+8 \mathrm{H}_{2} \mathrm{O}$, chemical reactions. Color code: hydrogen - white; oxygen - red; nitrogen - blue; ruthenium - green. 


\section{ARTICLE}

To study the relevance of the water molecules around of the coordination compounds in $\left[\mathrm{Ru}(\mathrm{HNO})\left(\mathrm{NH}_{3}\right)_{5}\right]^{3+}+\mathrm{H}_{2} \mathrm{O}$, $\left[\mathrm{Ru}(\mathrm{HNO})\left(\mathrm{H}_{2} \mathrm{O}\right)\left(\mathrm{NH}_{3}\right)_{5}\right]^{3+}$ and $\left[\mathrm{Ru}\left(\mathrm{H}_{2} \mathrm{O}\right)\left(\mathrm{NH}_{3}\right)_{5}\right]^{3+}+\mathrm{HNO}$ structures, the same reaction mechanism was studied considering now eight extra water molecules around the compounds: $\quad\left[\mathrm{Ru}(\mathrm{HNO})\left(\mathrm{NH}_{3}\right)_{5}\right]^{3+}+9 \mathrm{H}_{2} \mathrm{O} \rightarrow$ $\left[\mathrm{Ru}(\mathrm{HNO})\left(\mathrm{H}_{2} \mathrm{O}\right)\left(\mathrm{NH}_{3}\right)_{5}\right]^{3+}+8 \mathrm{H}_{2} \mathrm{O} \rightarrow\left[\mathrm{Ru}\left(\mathrm{H}_{2} \mathrm{O}\right)\left(\mathrm{NH}_{3}\right)_{5}\right]^{3+}+\mathrm{HNO}+$ $8 \mathrm{H}_{2} \mathrm{O}$ (Scheme 2). The energetic profile is different to the one showed in $\left[\mathrm{Ru}(\mathrm{HNO})\left(\mathrm{NH}_{3}\right)_{5}\right]^{3+}+\mathrm{H}_{2} \mathrm{O} \rightarrow\left[\mathrm{Ru}(\mathrm{HNO})\left(\mathrm{H}_{2} \mathrm{O}\right)\left(\mathrm{NH}_{3}\right)_{5}\right]^{3+}$ $\rightarrow\left[\mathrm{Ru}\left(\mathrm{H}_{2} \mathrm{O}\right)\left(\mathrm{NH}_{3}\right)_{5}\right]^{3+}+\mathrm{HNO}$. The $\Delta E$ value from $\left[\mathrm{Ru}(\mathrm{HNO})\left(\mathrm{NH}_{3}\right)_{5}\right]^{3+}+9 \mathrm{H}_{2} \mathrm{O}$ to $\left[\mathrm{Ru}\left(\mathrm{H}_{2} \mathrm{O}\right)\left(\mathrm{NH}_{3}\right)_{5}\right]^{3+}+\mathrm{HNO}+8 \mathrm{H}_{2} \mathrm{O}$ $\left(-4.57 \mathrm{kcal} \mathrm{mol}^{-1}\right)$ is lower than the one present in $\left[\mathrm{Ru}(\mathrm{HNO})\left(\mathrm{NH}_{3}\right)_{5}\right]^{3+}+\mathrm{H}_{2} \mathrm{O} \rightarrow\left[\mathrm{Ru}\left(\mathrm{H}_{2} \mathrm{O}\right)\left(\mathrm{NH}_{3}\right)_{5}\right]^{3+}+\mathrm{HNO}(21.59$ kcal $\left.\mathrm{mol}^{-1}\right)$, and now thermodynamically favorable. Next, the calculation shows the stabilization by solvation. Indeed, $\left[\mathrm{Ru}(\mathrm{HNO})\left(\mathrm{NH}_{3}\right)_{5}\right]^{3+}+9 \mathrm{H}_{2} \mathrm{O},\left[\mathrm{Ru}(\mathrm{HNO})\left(\mathrm{H}_{2} \mathrm{O}\right)\left(\mathrm{NH}_{3}\right)_{5}\right]^{3+}+8 \mathrm{H}_{2} \mathrm{O}$ and $\left[\mathrm{Ru}\left(\mathrm{H}_{2} \mathrm{O}\right)\left(\mathrm{NH}_{3}\right)_{5}\right]^{3+}+\mathrm{HNO}+8 \mathrm{H}_{2} \mathrm{O}$ structures have lower energy than $\left[\mathrm{Ru}(\mathrm{HNO})\left(\mathrm{NH}_{3}\right)_{5}\right]^{3+}+\mathrm{H}_{2} \mathrm{O}$, $\left[\mathrm{Ru}(\mathrm{HNO})\left(\mathrm{H}_{2} \mathrm{O}\right)\left(\mathrm{NH}_{3}\right)_{5}\right]^{3+}$ and $\left[\mathrm{Ru}\left(\mathrm{H}_{2} \mathrm{O}\right)\left(\mathrm{NH}_{3}\right)_{5}\right]^{3+}+\mathrm{HNO}$, respectively (Table S3). The most important point is that there is a significantly lower energetic barrier between $\left[\mathrm{Ru}(\mathrm{HNO})\left(\mathrm{NH}_{3}\right)_{5}\right]^{3+}+9 \mathrm{H}_{2} \mathrm{O}$ and $\left[\mathrm{Ru}(\mathrm{HNO})\left(\mathrm{H}_{2} \mathrm{O}\right)\left(\mathrm{NH}_{3}\right)_{5}\right]^{3+}+8 \mathrm{H}_{2} \mathrm{O}\left(4.99 \mathrm{kcal} \mathrm{mol}^{-1}\right)$ than in $\left[\mathrm{Ru}(\mathrm{HNO})\left(\mathrm{NH}_{3}\right)_{5}\right]^{3+}+\mathrm{H}_{2} \mathrm{O} \rightarrow\left[\mathrm{Ru}(\mathrm{HNO})\left(\mathrm{H}_{2} \mathrm{O}\right)\left(\mathrm{NH}_{3}\right)_{5}\right]^{3+}(31.80$ kcal mol-1), in agreement with the $\mathrm{Ru}-\mathrm{H}_{2} \mathrm{O}$ chemical bond formation and $\mathrm{Ru}-\mathrm{HNO}$ bond breaking processes occur earlier in $\left[\mathrm{Ru}(\mathrm{HNO})\left(\mathrm{NH}_{3}\right)_{5}\right]^{3+}+9 \mathrm{H}_{2} \mathrm{O} \rightarrow\left[\mathrm{Ru}(\mathrm{HNO})\left(\mathrm{H}_{2} \mathrm{O}\right)\left(\mathrm{NH}_{3}\right)_{5}\right]^{3+}+$ $8 \mathrm{H}_{2} \mathrm{O} \rightarrow\left[\mathrm{Ru}\left(\mathrm{H}_{2} \mathrm{O}\right)\left(\mathrm{NH}_{3}\right)_{5}\right]^{3+}+\mathrm{HNO}+8 \mathrm{H}_{2} \mathrm{O}$ than in $\left[\mathrm{Ru}(\mathrm{HNO})\left(\mathrm{NH}_{3}\right)_{5}\right]^{3+}+\mathrm{H}_{2} \mathrm{O} \rightarrow\left[\mathrm{Ru}(\mathrm{HNO})\left(\mathrm{H}_{2} \mathrm{O}\right)\left(\mathrm{NH}_{3}\right)_{5}\right]^{3+} \rightarrow$ $\left[\mathrm{Ru}\left(\mathrm{H}_{2} \mathrm{O}\right)\left(\mathrm{NH}_{3}\right)_{5}\right]^{3+}+\mathrm{HNO}$. In $\left[\mathrm{Ru}(\mathrm{HNO})\left(\mathrm{H}_{2} \mathrm{O}\right)\left(\mathrm{NH}_{3}\right)_{5}\right]^{3+}+8 \mathrm{H}_{2} \mathrm{O}$ compound, the $\mathrm{H}_{2} \mathrm{O}$ ligand already shows an almost linear configuration with $\mathrm{Ru}$ and $\mathrm{NH}_{3}$ trans ligand, while that in $\left[\mathrm{Ru}(\mathrm{HNO})\left(\mathrm{H}_{2} \mathrm{O}\right)\left(\mathrm{NH}_{3}\right)_{5}\right]^{3+}$ it is not visualized.

The results related the addition of water molecules also are supported by the increase of the entropy change $(\Delta S)$ from $\left[\mathrm{Ru}(\mathrm{HNO})\left(\mathrm{NH}_{3}\right)_{5}\right]^{3+}+\mathrm{H}_{2} \mathrm{O} \rightarrow\left[\mathrm{Ru}\left(\mathrm{H}_{2} \mathrm{O}\right)\left(\mathrm{NH}_{3}\right)_{5}\right]^{3+}+\mathrm{HNO}$ to $\left[\mathrm{Ru}(\mathrm{HNO})\left(\mathrm{NH}_{3}\right)_{5}\right]^{3+}+9 \mathrm{H}_{2} \mathrm{O} \rightarrow\left[\mathrm{Ru}\left(\mathrm{H}_{2} \mathrm{O}\right)\left(\mathrm{NH}_{3}\right)_{5}\right]^{3+}+\mathrm{HNO}+8 \mathrm{H}_{2} \mathrm{O}$ (3.11 and $21.18 \mathrm{cal} \mathrm{mol}^{-1} \mathrm{~K}^{-1}$, respectively). In the reaction with one water molecule, the $\Delta S$ value $\left(-1.24 \mathrm{cal} \mathrm{mol}^{-1} \mathrm{~K}^{-1}\right)$ of first step: $\left[\mathrm{Ru}(\mathrm{HNO})\left(\mathrm{NH}_{3}\right)_{5}\right]^{3+}+\mathrm{H}_{2} \mathrm{O} \rightarrow\left[\mathrm{Ru}(\mathrm{HNO})\left(\mathrm{H}_{2} \mathrm{O}\right)\left(\mathrm{NH}_{3}\right)_{5}\right]^{3+}$, is compensated by the $\Delta S$ value $\left(4.36 \mathrm{cal} \mathrm{mol}^{-1} \mathrm{~K}^{-1}\right)$ in the second step: $\left[\mathrm{Ru}(\mathrm{HNO})\left(\mathrm{H}_{2} \mathrm{O}\right)\left(\mathrm{NH}_{3}\right)_{5}\right]^{3+} \rightarrow\left[\mathrm{Ru}\left(\mathrm{H}_{2} \mathrm{O}\right)\left(\mathrm{NH}_{3}\right)_{5}\right]^{3+}+\mathrm{HNO}$. However, in the reaction with nine water molecules, the both steps: $\left[\mathrm{Ru}(\mathrm{HNO})\left(\mathrm{NH}_{3}\right)_{5}\right]^{3+}+9 \mathrm{H}_{2} \mathrm{O} \rightarrow\left[\mathrm{Ru}(\mathrm{HNO})\left(\mathrm{H}_{2} \mathrm{O}\right)\left(\mathrm{NH}_{3}\right)_{5}\right]^{3+}+$ $8 \mathrm{H}_{2} \mathrm{O}$ and $\left[\mathrm{Ru}(\mathrm{HNO})\left(\mathrm{H}_{2} \mathrm{O}\right)\left(\mathrm{NH}_{3}\right)_{5}\right]^{3+}+8 \mathrm{H}_{2} \mathrm{O} \rightarrow\left[\mathrm{Ru}\left(\mathrm{H}_{2} \mathrm{O}\right)\left(\mathrm{NH}_{3}\right)_{5}\right]^{3+}$ $+\mathrm{HNO}+8 \mathrm{H}_{2} \mathrm{O}$, respectively, contribute to increase the $\Delta S$ value (15.89 and $5.29 \mathrm{cal} \mathrm{mol}^{-1} \mathrm{~K}^{-1}$, respectively).

The charges obtained from atomic polar tensor (APT) for the $\left[\mathrm{Ru}\left(\mathrm{H}_{2} \mathrm{O}\right)\left(\mathrm{NH}_{3}\right)_{5}\right]^{3+}+\mathrm{HNO}+8 \mathrm{H}_{2} \mathrm{O}$ structure show that the $\mathrm{HNO}$ group has total charge close to zero $\left(\mathrm{q}_{\mathrm{HNO}}=0.019\right.$ a.u. $)$, while that the $\left[\mathrm{Ru}\left(\mathrm{H}_{2} \mathrm{O}\right)\left(\mathrm{NH}_{3}\right)_{5}\right]^{3+}$ complex and the remaining $8 \mathrm{H}_{2} \mathrm{O}$ molecules is 3.441 and -0.460 a.u., respectively. In the $\left[\mathrm{Ru}\left(\mathrm{H}_{2} \mathrm{O}\right)\left(\mathrm{NH}_{3}\right)_{5}\right]^{3+}$ coordination compound, the ruthenium atom appears with an atomic charge equal to 1.741 a.u., the $\mathrm{NH}_{3}$ ligands show total charges in a range from 0.292 to 0.382 a.u., and the $\mathrm{H}_{2} \mathrm{O}$ ligand has a charge value equivalent to 0.121 a.u. The eight non-bonded water molecules show an average total charge of -0.058 a.u. These results show that the solvation waters are able to accept a small amount of charges. Furthermore, the HNO ligand go out from the complex in its radical state while the ruthenium appears as $\mathrm{Ru}(\mathrm{II})$.

QTAIM analysis of the transition state: $\left[\mathrm{Ru}(\mathrm{HNO})\left(\mathrm{H}_{2} \mathrm{O}\right)\left(\mathrm{NH}_{3}\right)_{5}\right]^{3+}+8 \mathrm{H}_{2} \mathrm{O}$ shows that there are several Bond Critical Points (BCPs) between the leaving group HNO and two solvation water molecules. (Figure 1(a) and Table S4).

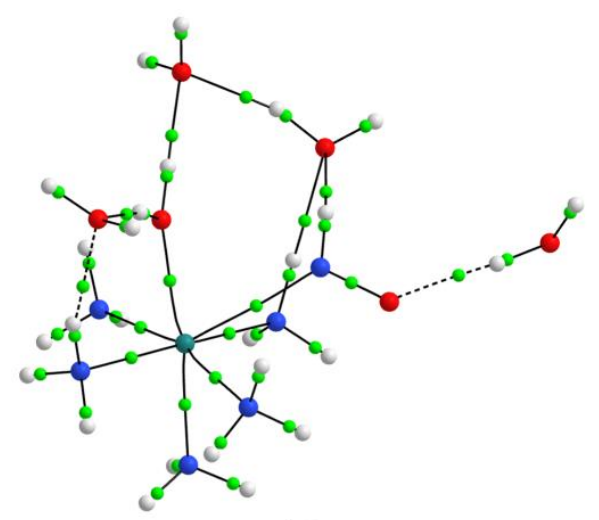

(a)

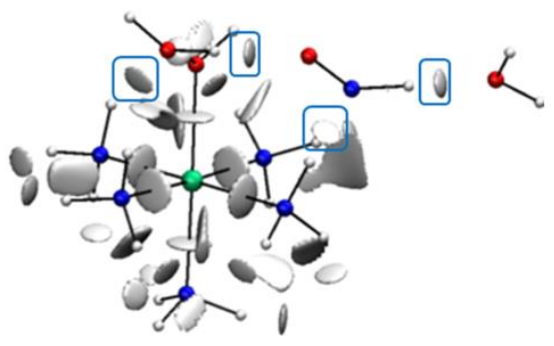

(b)

Fig. 1 (a) Topological map containing the bond paths (continuous or dashed lines connecting the cores), and bond critical points (green points) of the $\left[\mathrm{Ru}(\mathrm{HNO})\left(\mathrm{H}_{2} \mathrm{O}\right)\left(\mathrm{NH}_{3}\right)_{5}\right]^{3+}+8 \mathrm{H}_{2} \mathrm{O}$ complex; and (b) $\mathrm{NCl}$ for $\left[\mathrm{Ru}\left(\mathrm{H}_{2} \mathrm{O}\right)\left(\mathrm{NH}_{3}\right)_{5}\right]^{3+}+\mathrm{HNO}$ $+8 \mathrm{H}_{2} \mathrm{O}$ system with relevant hydrogen bonds highlighted with blue cases. $\left[\mathrm{Ru}(\mathrm{HNO})\left(\mathrm{H}_{2} \mathrm{O}\right)\left(\mathrm{NH}_{3}\right)_{5}\right]^{3+}+8 \mathrm{H}_{2} \mathrm{O}$ and $\left[\mathrm{Ru}\left(\mathrm{H}_{2} \mathrm{O}\right)\left(\mathrm{NH}_{3}\right)_{5}\right]^{3+}+\mathrm{HNO}+8 \mathrm{H}_{2} \mathrm{O}$ are without the five and six water molecules non-bonded to the HNO fragment or the Ru metal, respectively, to facilitate the visualization of the interactions involving the leaving group: $\mathrm{HNO}$, and the atoms colors are: white - hydrogen; red - oxygen; blue - nitrogen; green - ruthenium. 


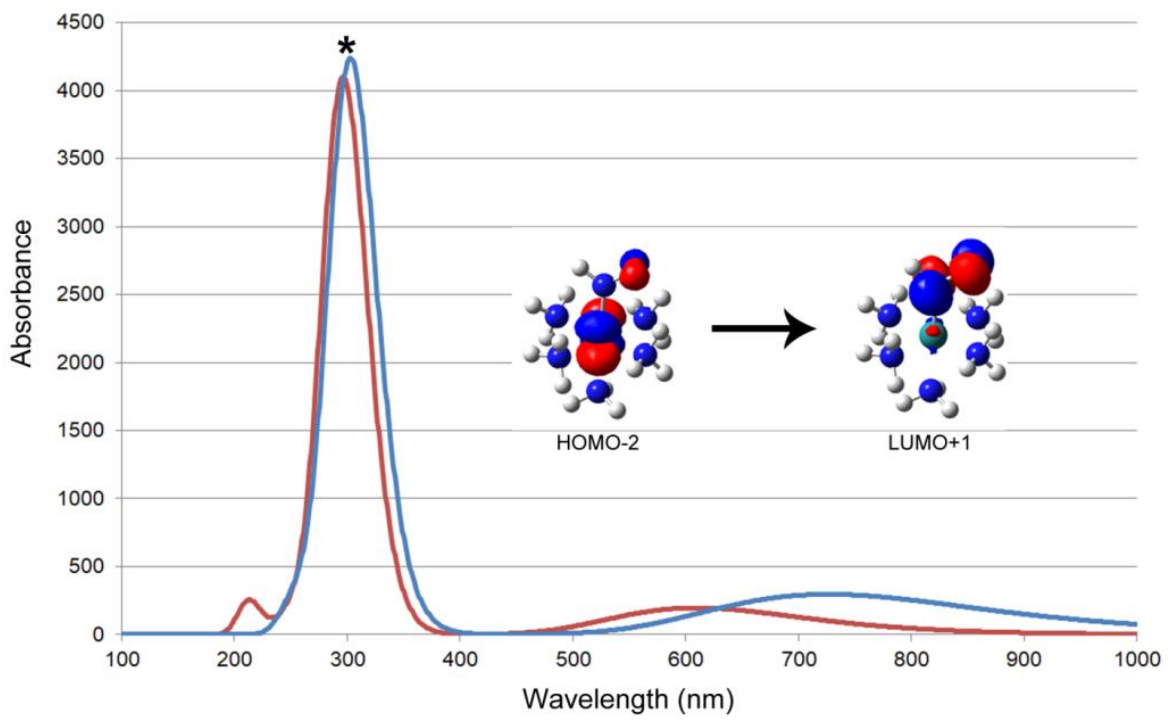

Fig. 2 Electronic absorption spectra of the $\left[\mathrm{Ru}(\mathrm{HNO})\left(\mathrm{NH}_{3}\right)_{5}\right]^{3+}+\mathrm{H}_{2} \mathrm{O}$ (red line) and $\left[\mathrm{Ru}(\mathrm{HNO})\left(\mathrm{NH}_{3}\right)_{5}\right]^{3+}+9 \mathrm{H}_{2} \mathrm{O}$ (blue line) with the transition, from $\mathrm{HOMO}-2 \rightarrow$ to $\mathrm{LUMO}+1$, in both the bands close to $300 \mathrm{~nm}$. The isovalue used to represent the molecular orbitals is $0.060 \mathrm{a} . \mathrm{u}$ and the atoms colors are: white - hydrogen; red - oxygen; blue - nitrogen; green ruthenium.

For the BCPs related to the $\mathrm{HNO} \cdots \mathrm{H}_{2} \mathrm{O}$ and $\mathrm{H}_{2} \mathrm{O} \cdots \mathrm{HNO}$ interactions, the $-G_{b} / V_{b}$ values (1.078 and 0.792 a.u., respectively) and $\nabla^{2} \rho_{\mathrm{b}}$ positive values $(0.088$ and 0.131 a.u., respectively) point out that these hydrogen bonds are strong (in the limit between covalency and closed shell). Furthermore, the electron density, $\rho_{b}$, in the $\mathrm{HNO} \cdots \mathrm{H}_{2} \mathrm{O}$ BCP is lower than the $\mathrm{H}_{2} \mathrm{O} \cdots \mathrm{HNO}$ one (0.024 and 0.055 a.u., respectively). NonCovalent Interactions $(\mathrm{NCl})$ results indicate for the $\left[\mathrm{Ru}\left(\mathrm{H}_{2} \mathrm{O}\right)\left(\mathrm{NH}_{3}\right)_{5}\right]^{3+}+\mathrm{HNO}+8 \mathrm{H}_{2} \mathrm{O}$ system interactions between the leaving group $\mathrm{HNO}$ and two water molecules, non-bonded to the metal (Figure $1(\mathbf{b})$ ). Typically, the NO compound has a larger capability to participate of $\pi$ orbital interactions than other small gas molecules, such as, $\mathrm{CO}_{2}$ and $\mathrm{CO} .{ }^{43}$

The HNO conversion to $\mathrm{NO}$ is usually associated with the oxidation of metalloproteins, such as the superoxide dismutase (SOD), 44 and related copper coordination compounds. ${ }^{45}$ In these compounds the HNO seems to be capable of reducing $\mathrm{Cu}(\mathrm{II})$ to $\mathrm{Cu}(\mathrm{I})$. The $\Delta E$ value for the $\left[\mathrm{Ru}\left(\mathrm{H}_{2} \mathrm{O}\right)\left(\mathrm{NH}_{3}\right)_{5}\right]^{3+}+\mathrm{HNO} \rightarrow\left[\mathrm{Ru}\left(\mathrm{H}_{2} \mathrm{O}\right)\left(\mathrm{NH}_{3}\right)_{5}\right]^{2+}+\mathrm{HNO}^{+}$chemical reaction is $41.52 \mathrm{kcal} \mathrm{mol}^{-1}$. Nevertheless, the $\Delta E$ value for $\mathrm{HNO}^{+}+\mathrm{H}_{2} \mathrm{O} \rightarrow \mathrm{H}_{3} \mathrm{O}^{+}+\mathrm{NO}$ is $-37.65 \mathrm{kcal} \mathrm{mol}^{-1}$. Hence, the $\mathrm{HNO}$ conversion to NO after the release from the ruthenium ammine coordination compounds is plausible to occur.

The NO release mechanism involving light irradiation is supported mainly by the electronic transition: $\operatorname{Ru}\left(d_{\pi}\right) \rightarrow \pi^{*}$ NO
It decreases the $\pi$ back-donation process present in the Ru$\mathrm{NO}$ bond, which is the key element for retaining the Ru-NO interaction. $^{21}$ Hence, this radiation facilitates the NO substitution reaction, $\left[\mathrm{Ru}(\mathrm{NO})\left(\mathrm{NH}_{3}\right)_{5}\right]^{3+}+\mathrm{H}_{2} \mathrm{O}+\mathrm{hv} \rightarrow$ $\left[\mathrm{Ru}\left(\mathrm{H}_{2} \mathrm{O}\right)\left(\mathrm{NH}_{3}\right)_{5}\right]^{3+}+\mathrm{NO}$. Nevertheless, experimental and theoretical evidences show that the $\mathrm{Ru}\left(\mathrm{d}_{\pi}\right) \rightarrow \pi^{*}$ NO transition in the $\left[\mathrm{Ru}(\mathrm{NO})\left(\mathrm{NH}_{3}\right)_{5}\right]^{3+}$ compound, ${ }^{46,47}$ appears in the spectrum range between $390-480 \mathrm{~nm}$ with low absorption coefficient.

As an alternative mechanism, the light irradiation of the products created from: i) $\left[\mathrm{Ru}(\mathrm{NO})\left(\mathrm{NH}_{3}\right)_{5}\right]^{3+}+\mathrm{e}^{-} \rightarrow$ $\left[\mathrm{Ru}(\mathrm{NO})\left(\mathrm{NH}_{3}\right)_{5}\right]^{2+} ;$ and ii) $\left[\mathrm{Ru}(\mathrm{NO})\left(\mathrm{NH}_{3}\right)_{5}\right]^{2+}+\mathrm{H}_{3} \mathrm{O}^{+} \rightarrow$ $\left[\mathrm{Ru}(\mathrm{HNO})\left(\mathrm{NH}_{3}\right)_{5}\right]^{3+}+\mathrm{H}_{2} \mathrm{O}$, with one or nine water molecules around the complex: $\left[\mathrm{Ru}(\mathrm{HNO})\left(\mathrm{NH}_{3}\right)_{5}\right]^{3+}+\mathrm{H}_{2} \mathrm{O}$ and $\left[\mathrm{Ru}(\mathrm{HNO})\left(\mathrm{NH}_{3}\right)_{5}\right]^{3+}+9 \mathrm{H}_{2} \mathrm{O}$, respectively, are expected to produce a more efficient route to NO release. This can be visualized from their electronic spectra (Figure 2). The most important electronic transition in $\left[\mathrm{Ru}(\mathrm{HNO})\left(\mathrm{NH}_{3}\right)_{5}\right]^{3+}+\mathrm{H}_{2} \mathrm{O}$ and $\left[\mathrm{Ru}(\mathrm{HNO})\left(\mathrm{NH}_{3}\right)_{5}\right]^{3+}+9 \mathrm{H}_{2} \mathrm{O}$ to facilitate the $\mathrm{NO}$ release is the HOMO-2 $\left[\mathrm{Ru}\left(\mathrm{d}_{\pi}\right)\right] \rightarrow$ LUMO+1 $\left(\pi^{*} \mathrm{HNO}\right)$, which occurs in a range close to the visible region $(\sim 300 \mathrm{~nm})$ with a good absorbance. 


\section{Conclusions}

Therefore, we have analyzed the traditional nitric oxide release mechanism: i) $\left[\mathrm{Ru}(\mathrm{NO})\left(\mathrm{NH}_{3}\right)_{5}\right]^{3+}+\mathrm{e}^{-} \rightarrow$ $\left[\mathrm{Ru}(\mathrm{NO})\left(\mathrm{NH}_{3}\right)_{5}\right]^{2+}$; and ii) $\left[\mathrm{Ru}(\mathrm{NO})\left(\mathrm{NH}_{3}\right)_{5}\right]^{2+}+\mathrm{H}_{2} \mathrm{O} \rightarrow$ $\left[\mathrm{Ru}\left(\mathrm{H}_{2} \mathrm{O}\right)\left(\mathrm{NH}_{3}\right)_{5}\right]^{2+}+\mathrm{NO}$ and the energetic profile between the reactants and products has a transition state that is thermodynamically and kinetically unlikely to happen.

Thus, an improved mechanism was proposed for the ligand substitution reaction involving the protonation of the $\left[\mathrm{Ru}(\mathrm{NO})\left(\mathrm{NH}_{3}\right)_{5}\right]^{2+}$ reduced species: i) $\left[\mathrm{Ru}(\mathrm{NO})\left(\mathrm{NH}_{3}\right)_{5}\right]^{2+}+\mathrm{H}_{3} \mathrm{O}^{+}$ $\rightarrow\left[\mathrm{Ru}(\mathrm{HNO})\left(\mathrm{NH}_{3}\right)_{5}\right]^{3+}+\mathrm{H}_{2} \mathrm{O}$; and ii) $\left[\mathrm{Ru}(\mathrm{HNO})\left(\mathrm{NH}_{3}\right)_{5}\right]^{3+}+\mathrm{H}_{2} \mathrm{O}$ $\rightarrow\left[\mathrm{Ru}\left(\mathrm{H}_{2} \mathrm{O}\right)\left(\mathrm{NH}_{3}\right)_{5}\right]^{3+}+\mathrm{HNO}$, which also shows one transition state. The addition of eight explicit water molecules shows conformations more promising to release the HNO group in relation to the another mechanisms investigated above.

The QTAIM method shows the existence of interactions between the leaving group HNO and two water molecules, non-bonded to ruthenium. The HNO conversion route to NO after the release from $\mathrm{Ru}-\mathrm{NH}_{3}$ complexes is thermodynamically accessible, $\left[\mathrm{Ru}\left(\mathrm{H}_{2} \mathrm{O}\right)\left(\mathrm{NH}_{3}\right)_{5}\right]^{3+}+\mathrm{HNO} \rightarrow$ $\left[\mathrm{Ru}\left(\mathrm{H}_{2} \mathrm{O}\right)\left(\mathrm{NH}_{3}\right)_{5}\right]^{2+}+\mathrm{HNO}^{+}\left(41.56 \mathrm{kcal} \mathrm{mol}^{-1}\right)$ and $\mathrm{HNO}^{+}+\mathrm{H}_{2} \mathrm{O}$ $\rightarrow \mathrm{H}_{3} \mathrm{O}^{+}+\mathrm{NO}\left(-37.30 \mathrm{kcal} \mathrm{mol}^{-1}\right)$.

The light irradiation of the $\left[\mathrm{Ru}(\mathrm{HNO})\left(\mathrm{NH}_{3}\right)_{5}\right]^{3+}$ structure showed the $\mathrm{Ru}\left(\mathrm{d}_{\pi}\right) \rightarrow \pi^{*}(\mathrm{HNO})$ transition with an applicable absorbance and present in a region close to visible range ( $300 \mathrm{~nm}$ ). Thus, this light supported mechanism can be used to favor the kinetics of the reaction pathway: $\left[\mathrm{Ru}(\mathrm{HNO})\left(\mathrm{NH}_{3}\right)_{5}\right]^{3+}+$ $\mathrm{H}_{2} \mathrm{O} \rightarrow\left[\mathrm{Ru}\left(\mathrm{H}_{2} \mathrm{O}\right)\left(\mathrm{NH}_{3}\right)_{5}\right]^{3+}+\mathrm{HNO}$

\section{Conflicts of interest}

There are no conflicts to declare.

\section{Acknowledgements}

This study was financed in part by the Coordenação de Aperfeiçoamento de Pessoal de Nível Superior - Brasil (CAPES) Finance Code 001. RLTP, RPO, GCGS and NHM thank grants 2011/07623-8, 2017/24856-2, 2019/00543-0, and 2013/08293-7 São Paulo Research Foundation (FAPESP) for the financial support. GN and MJP thank the Rio Grande do Sul Research Foundation (FAPERGS), National Council for Scientific and Technological Development (CNPq, 306297/2018-3). GFC and NHM thank CNPq (311963/2017-0, and 303581/2018-2, respectively) for the research fellowship. JCG thanks CALSIMLAB under the public grant ANR-11-LABX-0037-01, overseen by the French National Research Agency (ANR) as part of the Investissements d'Avenir program (reference: ANR11-IDEX-0004-02).

\section{References}

1 J. R. Lancaster, Jr. Am. Sci., 1992, 80, 248-259.

2 J. R. Lancaster, Jr. Nitric Oxide, 1997, 1, 18-30.

3 J. R. Lancaster, Jr. Future Sci. OA, 2015, 1, FSO59.
4 B. J. Finlayson-Pitts and J. N. Pitts, Atmospheric Chemistry: Fundamentals and Experimental Techniques, WileyIntersciencem, New York, 1986.

5 S. H. Snyder and D. S. Bredt, Sci. Am., 1992, 266, 68-71.

6 D. A. Wink and J. B. Mitchell, Free Radic. Biol. Med., 1998, 25, 434-456.

7 L. J. Ignarro, Nitric Oxide: Biology and Pathobiology, Academic Press, New York, 2000.

8 D. D. Thomas, L. A. Ridnour, J. S. Isenberg, W. FloresSantana, C. H. Switzer, S. Donzelli, P. Hussain, C. Vecoli, N. Paolocci, S. Ambs, C. A. Colton, C. C. Harris, D. D. Roberts and D. A. Wink, Free Radic. Biol. Med., 2008, 45, 18-31.

9 J. C. Toledo Jr. and O. Augusto, Chem. Res. Toxicol., 2012, 25, 975-989.

10 E. Tfouni, F. G. Doro, A. J. Gomes, R. S. da Silva, G. Metzker P. G. Zanichelli Benini and D. W. Franco, Coord. Chem. Rev., 2010, 254, 355-371.

11 G. F. Caramori and G. Frenking, Organometallics, 2007, 26, 5815-5825.

12 G. F. Caramori and G. Frenking, Croat. Chem. Acta, 2009, 82, 219-232.

13 F. G. Doro, K. Q. Ferreira, Z. N. da Rocha, G. F. Caramori, A. J. Gomes and E. Tfouni, Coord. Chem. Rev., 2016, 306, 652677.

14 J. C. Toledo, H. A. S. Silva, M. Scarpellini, V. Mori, A. J. Camargo, M. Bertotti and D. W. Franco, Eur. J. Inorg. Chem., 2004, 2004, 1879-1885.

15 E. Tfouni, M. Krieger, B. R. McGarvey and D. W. Franco, Coord. Chem. Rev., 2003, 236, 57-69.

16 M. J. Rose and P. K. Mascharak, Coord. Chem. Rev., 2008, 252, 2093-2114.

17 M. Guo, H. J. Xiang, Y. Wang, Q. L. Zhang, L. An, S. P. Yang, Y. Ma, Y. Wang, J. G. Liu and J. Gang, Chem. Commun., 2017, 53, 3253-3256.

18 G. L. S. Rodrigues and W. R. Rocha, J. Phys. Chem. B, 2016, 120, 11821-11833

19 M. Roose, M. Tassé, P. G. Lacroix and I. Malfant, New J. Chem., 2019, 43, 755-767.

20 R. P. Orenha, R. T. Santiago, R. L. A. Haiduke and S. E. Galembeck, J. Comput. Chem., 2017, 38, 883-891.

21 R. P. Orenha, M. V. J. Rocha, J. Poater, S. E. Galembeck and F. M. Bickelhaupt, ChemistryOpen, 2017, 6, 410-416.

22 R. P. Orenha, E. Tfouni and S. E. Galembeck, Phys. Chem. Chem. Phys., 2018, 20, 13348-13356.

23 J. A. Luque-Urrutia and A. Poater, Inorg. Chem., 2017, 56, 14383-14387.

24 L. Yao, Y. Li, L. Huang, K. Guo, G. Ren, Z. Wua, Q. Lei, W. Fang and H. Xie, Comput. Theor. Chem., 2018, 1128, 48-55.

25 J. P. Perdew, K. Burke and M. Ernzerhof, Phys. Rev. Lett., 1996, 77, 3865-3868.

26 J. P. Perdew, K. Burke and M. Ernzerhof, Phys. Rev. Lett., 1997, 78, 1396.

27 C. Adamo and V. Barone, J. Chem. Phys., 1999, 110, 61586169.

28 F. Weigend and R. Ahlrichs, Phys. Chem. Chem. Phys., 2005, 7, 3297-3305.

29 F. Weigend, Phys. Chem. Chem. Phys., 2006, 8, 1057-1065.

30 C. Peng and H. B. Schlegel, Israel J. Chem., 1993, 33, 449454.

31 S. Grimme, J. Antony, S. Ehrlich and H. Krieg, J. Chem. Phys. 2010, 132, 154104.

32 J. Tomasi, B. Mennucci and R. Cammi, Chem. Rev., 2005, 105, 2999-3093.

33 J. A. Cioslowski, J. Am. Chem. Soc., 1989, 111, 8333-8836.

34 M. J. Frisch, G. W. Trucks, H. B. Schlegel, G. E. Scuseria, M. A Robb, J. R. Cheeseman, G. Scalmani, V. Barone, G. A Petersson, H. Nakatsuji, X. Li, M. Caricato, A. V. Marenich, J. Bloino, B. G. Janesko, R. Gomperts, B. Mennucci, H. P. 
Hratchian, J. V. Ortiz, A. F. Izmaylov, J. L. Sonnenberg, D. Williams-Young, F. Ding, F. Lipparini, F. Egidi, J. Goings, B. Peng, A. Petrone, T. Henderson, D. Ranasinghe, V. G. Zakrzewski, J. Gao, N. Rega, G. Zheng, W. Liang, M. Hada, M. Ehara, K. Toyota, R. Fukuda, J. Hasegawa, M. Ishida, T. Nakajima, Y. Honda, O. Kitao, H. Nakai, T. Vreven, K. Throssell, J. A. Montgomery Jr., J. E. Peralta, F. Ogliaro, M. J. Bearpark, J. J. Heyd, E. N. Brothers, K. N. Kudin, V. N. Staroverov, T. A. Keith, R. Kobayashi, J. Normand, K. Raghavachari, A. P. Rendell, J. C. Burant, S. S. Iyengar, J. Tomasi, M. Cossi, J. M. Millam, M. Klene, C. Adamo, R. Cammi, J. W. Ochterski, R. L. Martin, K. Morokuma, O. Farkas, J. B. Foresman and D. J. Fox, GAUSSIAN 16 (Revision A.03), Gaussian Inc., Wallingford, CT, 2016.

35 T. A. Keith, AlMAll, Revision 17.01.25, 2017, TK Gristmill Software, Overland Park KS, USA.

36 E. R. Johnson, S. Keinan, P. Mori-Sanchez, J. ContrerasGarcia, A. J. Cohen and W. Yang, J. Am. Chem. Soc., 2010, 132, 6498-6506.

37 J. Contreras-Garcia, E. Johnson, S. Keinan, R. Chaudret, J.-P. Piquemal, D. Beratan and W. Yang, J. Chem. Theor. Comp., 2011, 7, 625-632.

38 R. F. W. Bader, Atoms and Molecules - A Quantum Theory, Claredon Press, Oxford, New York, 1994.

39 G. F. Caramori, R. L. T. Parreira and A. M. da Costa Ferreira, Int. J. Quantum Chem., 2012, 112, 625-646.

40 F. Bottomley, J. Chem. Soc., Dalton Trans., 1974, 15, 16001605.

41 R. P. Orenha, L. R. San Gregorio and S. E. Galembeck, J. Mol. Model., 2016, 22, 276.

42 H. Ryu, J. Park, H. K. Kim, J. Y. Park, S.-T. Kim and M.-H. Baik, Organometallics, 2018, 37, 3228-3239.

43 J. Poater, M. Gimferrer and A. Poater, Inorg. Chem., 2018, 57, 6981-6990.

44 J. M. Fukuto, A. J. Hobbs and L. J. Ignarro, Biochem. Biophys. Res. Commun., 1993, 196, 707-713.

45 M. A. Michael, G. Pizzella, L. Yang, Y. Shi, T. Evangelou, D. T. Burke and Y. J. Zhang, Phys. Chem. Lett., 2014, 5, 1022-1026.

46 A. F. Schreiner, S. W. Lin, P. J. Hauser, E. A. Hopcus, D. J. Hamm and J. D. Gunter, Inorg. Chem., 1972, 11, 880-888.

47 A. P. de Lima Batista, A. G. S. de Oliveira-Filho and S. E. Galembeck, Phys. Chem. Chem. Phys., 2017, 19, 1386013867. 